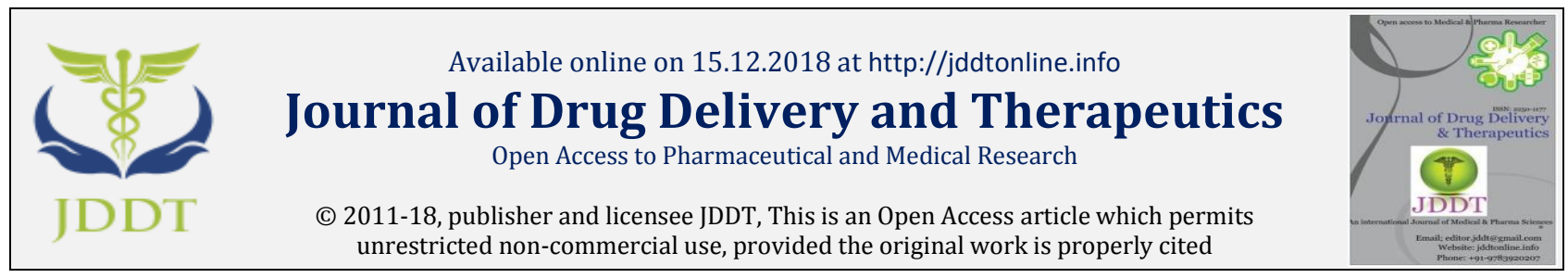

Open $\odot$ Access

Review Article

\title{
Gruhadhuma in Agada Yogas: a review
}

\section{Gazala Hussain ${ }^{1 *}$, Vinay R Kadibagil ${ }^{2}$}

*1 Associate Professor, Dept. of Rasashastra \& Bhaishajya Kalpana, Sri Dharmasthala Manjunatheshwara College of Ayurveda \& Hospital, Hassan, Karnataka 573201, India

2 Professor, Dept. of Rasashastra \& Bhaishajya Kalpana, Sri Dharmasthala Manjunatheshwara College of Ayurveda \& Hospital, Hassan, Karnataka 573201, India

\section{ABSTRACT}

Gruhadhuma is an ingredient mentioned in Ayurveda pharmaceutics in a group of drugs termed as panchamrittika. It is an ingredient that is used in various formulations in the treatment of vishas (poisons). Many formulations for the management of various poisons like snake bite, keetavisha (insect poisons), etc. have been explained in Ayurveda treatise that contains it as an ingredient. The agada yogas (formulations for poisonous bites) mentioned for the management of various poisons in bruhatrayee contain ingredients that are both herbal and mineral in origin. Formulations having gruhadhuma have been mentioned for oral administration, as nasya (nasal inhalation), anjana (collyrium), lepa (anointment), etc. A literary search through the treatises of Ayurveda has put a light on the various formulations containing it.

Keywords: Agadayogas, Gruhadhuma, poisons, formulations.

Article Info: Received 20 Oct, 2018; Review Completed 03 Dec 2018; Accepted 04 Dec 2018; Available online 15 Dec 2018

Cite this article as:

Hussain G, Kadibagil VR, Gruhadhuma in Agada Yogas: a review, Journal of Drug Delivery and Therapeutics. 2018; 8(6s):370-372 DOI: http://dx.doi.org/10.22270/jddt.v8i6-s.2106

\section{*Address for Correspondence:}

Dr Gazala Hussain, Associate Professor, Dept. of Rasashastra \& Bhaishajya Kalpana, Sri Dharmasthala Manjunatheshwara College of Ayurveda \& Hospital, Hassan, Karnataka 573201, India

\section{INTRODUCTION}

A literary review through the samhitas (treatise) of Ayurveda with reference to the management of various poisons has led light on Gruhadhuma being used in agada yogas (formulations in treatment of poisons). Both internal administration and external use of these formulations have been mentioned.

Gruhadhuma is the chimney soot. It is mentioned as one of the panchamrittika (five types of mud) in the text books of Indian alchemy. Panchamrittika in Ayurveda pharmaceutics is used for the purification of metals ${ }^{1}$.

\section{Yogas containing Gruhadhuma in Charaka Samhita:}

In Rajimantha Visha (krait poison), Gruhadhuma (chimney soot) with Shunti, Maricha, Pippali, Ativisha, Kushta,
Harenu, Tagara and Katuka is said to be used internally, ${ }^{2}$ in Vasuki sarpavisha (celestial snakes) gruhadhuma with Haridra, Daruharidra, Tanduliyaka along with madhu (honey) and ghrita (ghee) is explained to be taken internally ${ }^{3}$.

Vachadi agada is mentioned to be administered as nasya (nasal therapy), anjana (collyrium), lepa (anointment) in cases of visha (poison). It has Vacha, Vamsha, Pata, Nata, Tulasi, Bala, Mahabala, Nakuli, Kushta, Shirisha, Haridra, Daruharidra, Guha, Atiguha, Swetha Ajagandha, Shilajatu, Katruna, Katabhi, Kshara, Gruhadhuma, Manahshila- these drugs are triturated with the bile of Rohita (a type of fish) and made into a paste and used.

Table 1: Yogas containing Gruhadhuma in Ashtanga Sangraha

\begin{tabular}{|l|l|l|l|l|}
\hline $\begin{array}{l}\text { Sl. } \\
\text { No. }\end{array}$ & Yoga & Ingredients & Indications & $\begin{array}{l}\text { Mode of } \\
\text { administration }\end{array}$ \\
\hline 1 & $\begin{array}{l}\text { Mrutasanjeevana } \\
\text { Agada }^{4}\end{array}$ & $\begin{array}{l}\text { Nimba (Azadirachta indica), Gruhadhuma, Phanita, } \\
\text { Bruhati mixed with Gopitta (bile of cow) }\end{array}$ & $\begin{array}{l}\text { In all types of } \\
\text { visha (poison) }\end{array}$ & Internal use \\
\hline 2 & Prajapatya agada $^{5}$ & $\begin{array}{l}\text { Trivrut (Operculina turpethum), Gorochana, Trikatu, } \\
\text { Vacha (Acorus calamus) }\end{array}$ & $\begin{array}{l}\text { In all types of } \\
\text { visha (poison) }\end{array}$ & Internal use \\
\hline 3 & Maheshwara yoga $^{6}$ & $\begin{array}{l}\text { Ashwagandha (Withania somnifera), Gruhadhuma, } \\
\text { Guggulu (Commiphora wightii), triturated with }\end{array}$ & $\begin{array}{l}\text { In all types of } \\
\text { visha (poison) }\end{array}$ & Internal use \\
\hline
\end{tabular}




\begin{tabular}{|c|c|c|c|c|}
\hline & & Gomutra (Cow's urine) & & \\
\hline 4 & $\begin{array}{l}\text { Gruhadhumadi } \\
\text { panam }^{7}\end{array}$ & $\begin{array}{l}\text { Gruhadhuma, Haridra (Curcuma longa), Daruharidra } \\
\text { (Berberis aristata), Tanduliyamoola (Amaranthus } \\
\text { viridis) }\end{array}$ & $\begin{array}{l}\text { In Vasuki } \\
\text { sarpavisha } \\
\text { (snake poison) }\end{array}$ & $\begin{array}{l}\text { Internal } \\
\text { administration } \\
\text { With madhu } \\
\text { (honey) and Ghrita } \\
\text { (ghee) }\end{array}$ \\
\hline 5 & Vachadi Agada ${ }^{8}$ & $\begin{array}{l}\text { Vacha (Acorus calamus), Vamsha (Bambusa } \\
\text { arundinacea), Pata (Tragiain volucrata), Tagara } \\
\text { (Valeriana wallichii), Tulasi (Ocimum sanctum), Bala } \\
\text { (Sida cordifolia), Atibala (Abutilon indicum), Rasna } \\
\text { (Pluchea lanceolata), Kushta (Saussurea lappa), } \\
\text { Shirisha (Albizia lebbeck), Haridra (Curcuma longa), } \\
\text { Daruharidra (Berberis aristata), Shalaparni } \\
\text { (Desmodium gangeticum), Prushnaparni (Hedysarum } \\
\text { pictum), Ajagandha (Cleome gynandra), Shilajatu (Black } \\
\text { bitumen), Katruna, Katabhi (Celastrus paniculatus), } \\
\text { Yavakshara, Gruhadhuma, Manahshila (Realgar), } \\
\text { Rohitaka (Tecomella undulata) - these have to be } \\
\text { triturated with Gopitta }\end{array}$ & $\begin{array}{l}\text { In Keetavisha } \\
\text { (insect poison) }\end{array}$ & $\begin{array}{l}\text { As anointment, } \\
\text { collyrium, internal } \\
\text { usage }\end{array}$ \\
\hline 6 & Ksharagada ${ }^{9}$ & $\begin{array}{l}\text { Dhava (Anogeissus latifolia), Asana (Pterocarpus } \\
\text { marsupium), Tinisha (Ougeinia dalbergioides), } \\
\text { Madanaphala (Randia dumetorum), Palasha (Butea } \\
\text { monosperma), Amrataka (Spondia spinnata), Arjuna } \\
\text { (Terminalia arjuna), Paribhadra (Erythrina variegata), } \\
\text { Lodhra (Symplocos racemosa), Kapittha (Limonia } \\
\text { acidissima), Kutaja (Holarrhena antidysenterica), } \\
\text { Ankola (Alangium salviifolium), Karanja (Pongami } \\
\text { apinnata), Amalaki (Emblica officinalis), Bujapatra, } \\
\text { Shami (Prosopis cineraria), Shleshmataka (Cordia } \\
\text { dichotoma), Ashmanta, Gojihwa (Onosma bracteatum), } \\
\text { Kantaka, Chirabilwa (Holoptelea integrifolia), Arka } \\
\text { (Calotropis gigantea), Shyonaka ( Oroxylum indicum), } \\
\text { Manjishta (Rubia cordifolia), Shigru (Moringa oleifera), } \\
\text { Gopagontha, Karaveera (Nerium indicum)- bhasmas of } \\
\text { these drugs should be made; Gomutra is mixed in it } \\
\text { filtered like the way of preparation of ksharajala and } \\
\text { when it solidifies the powders of drugs of Pippali (Piper } \\
\text { longum), Gajapippali (Scindapsus officinalis), Koshamra, } \\
\text { Saptaparna (Alstonia scholaris), Elavaluka (Brunu } \\
\text { scerasus), Varanga, Ela (Elettaria cardamomum), } \\
\text { Manjishta (Rubia cordifolia), Kushta (Saussurea lappa), } \\
\text { Jalavetasa, Shyonaka (Oroxylum indicum), Vidanga } \\
\text { (Embelia ribes), Atasi (Linum usitaissimum), Sariva } \\
\text { (Hemidesmus indicus), Sarshapa (Brassica nigra), } \\
\text { Tanduliya (Amaranthus viridis), Devadaru (Cedrus } \\
\text { deodara), Saralakashta, Plaksha (Ficus lacor), } \\
\text { Gruhadhuma, Karanja (Pongamia pinnata), Nagadanti } \\
\text { (Croton oblongifolius), Dravanti (Jatropha glandulifera), } \\
\text { Jalavetasa, Varuna (Cratae vanurvala), Vacha (Acorus } \\
\text { calamus), Eranda (Ricinus communis), Bilwa (Aegle } \\
\text { marmelos ), Loha (iron) these are added and stored in } \\
\text { iron vessel }\end{array}$ & $\begin{array}{l}\text { Sthavara and } \\
\text { jangama visha } \\
\text { (animal and } \\
\text { plant poison) }\end{array}$ & $\begin{array}{l}\text { Internal } \\
\text { administration }\end{array}$ \\
\hline
\end{tabular}

\section{Other than the above formulations, a few combinations mentioned are:}

\section{In Snake bite:}

In case of Darvikara (cobra bite) visha, Gruhadhuma (chimney soot) is mixed with Madhu (honey), Manjishta (Rubia cordifolia) and given orally and is said to be best ${ }^{10}$. In Rajimantha visha, a combination of Gruhadhuma (chimney soot) with Katuka (Picrorhiza kurrooa), Ativisha (Aconitum heterophyllum), Kushta (Saussurea lappa), Tagara (Valeriana wallichii), Trikatu (combination of Zingiber officinale, Piper nigrum and Piper longum), Harenu (Pisum sativum), etc. is said for oral administration to lick it ${ }^{11}$.

\section{In Mushikavisha:}

A combination of Gruhadhuma (chimney soot) with Manjishta (Rubia cordifolia), Haridra (Curcuma longa) and Saindhava lavana (Rock salt) is said to be used as an anointment. 12

In other conditions: Gruhadhuma with Nata (Valeriana wallichii), Shyama (Ocimum sanctum), Neelini (Indigofer atinctoria), Tanduliya (Amaranthus spinosus) prepared in the form of Ghrita (Ghee) is said to reduce the bastivedana (pain in urinary system) and anaha (Distension of abdomen due to obstruction to passage of urine and stools) in the complications caused because of visha ${ }^{13}$.

Ghrita prepared with Bharangi (Clerodendrum serratum), Dadhi (curd), gruhadhuma (chimney soot), Sariva 
(Hemidesmus indicus), Tanduliya (Amaranthus spinosus) or a combination of Gruhadhuma with Manjishta (Rubia cordifolia) and Yashti (Glycyrrhiza glabra) in ghrita form is said in the management of Teekshnavisha (strong poisons). ${ }^{14}$

Gruhadhuma (chimney soot) with Manashila (Realgar), Dwiksharas (alkalies), Trikatu (combination of Zingiber officinale, Piper nigrum and Piper longum) and other herbal drugs mixed with Ajamutra (Goat's urine) is said to be Kushtaghna (skin diseases). ${ }^{15}$

\section{Yogas containing Gruhadhuma in Ashtanga Hrudaya}

Intake of ghee with madhu (honey), Manjishta (Rubia cordifolia) and Gruhadhuma (chimney soot) is said for the management of Krishnasarpadashta chikitsa (snake bite). 16 A combination with Gruhadhuma (chimney soot) with Katuka (Picrorhiza kurrooa), Ativisha (Aconitum heterophyllum), Kushta (Saussurea lappa), Harenu (Pisum sativum), Trikatu (combination of Zingiber officinale, Piper nigrum and Piper longum), Tagara (Valeriana wallichii) with madhu (honey) orally is said to be beneficial in the management of Rajimantha visha (Krait bite). ${ }^{17}$

In mushika damsha (rat poison), an anointment with Gruhadhuma (chimney soot), Manjishta (Rubia cordifolia), Haridra (Curcuma longa) and Saindhava lavana (Rock salt) is mentioned. 18

\section{Yogas containing Gruhadhuma in Sushruta Samhita}

In Trikantakavisha (a type of flying insect) Kushtadi agada is mentioned having the ingredients namely Gruhadhuma (chimney soot) with Haridra (Curcuma longa), Daruharidra (Berberis aristata), Kushta (Saussurea lappa), Tagara

\section{REFERENCES}

1. Sharma Sadanand. Rasa Tarangini, $11^{\text {th }}$ Edition, Delhi; Motilal Banarasidas; 2000:14

2. Tripathi Brahmanand. Charaka Samhita of Agnivesha, Chapter 23, verse 197. Reprint Edition, Varanasi; Chaukhamba Surabahrati Prakashan; 2004: 792

3. Tripathi Brahmanand. Charaka Samhita of Agnivesha, Chapter 23, verse 198. Reprint Edition, Varanasi; Chaukhamba Surabahrati Prakashan; 2004: 792

4. K. R Srikantha Murthy. Ashtanga Sangraha of Vagbhata.

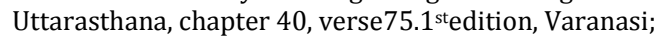
Chaukambha Orientalia: 1997:361

5. K. R Srikantha Murthy. Ashtanga Sangraha of Vagbhata.Uttarasthana, chapter 40, verse 82. 1 1 1 stedition, Varanasi; Chaukambha Orientalia: 1997:362

6. K. R Srikantha Murthy. Ashtanga Sangraha of Vagbhata.

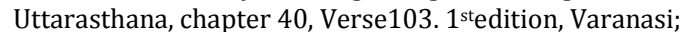
Chaukambha Orientalia: 1997:364

7. K. R Srikantha Murthy. Ashtanga Sangraha of

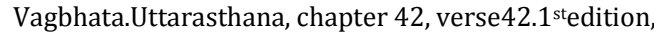
Varanasi; Chaukambha Orientalia: 1997:395

8. K. R Srikantha Murthy. Ashtanga Sangraha of Vagbhata.Uttarasthana, chapter 43, verse 57-59. $1^{\text {stedition, }}$ Varanasi; Chaukambha Orientalia: 1997:411

9. K. R Srikantha Murthy. Ashtanga Sangraha of Vagbhata. Uttarasthana, chapter 43, verse 50-58. $1^{\text {stedition, Varanasi }}$ Chaukambha Orientalia: 1997:447

10. K. R Srikantha Murthy. Ashtanga Sangraha of Vagbhata.Uttarasthana, chapter 42, verse 29.1 ${ }^{\text {st }}$ edition, Varanasi; Chaukambha Orientalia: 1997:393
(Valeriana wallichii), Vacha (Acorus calamus), Pata (Cyclea peltata), Bilwamoola (root of Aegle marmelos), Souvarchala lavana is said to be beneficial. ${ }^{19}$

In Galagolikavisha (type of insect) Rajanyadi agada is mentioned that has Haridra (Curcuma longa), Gruhadhuma (chimney soot), Tagara (Valeriana wallichii), Kushta (Saussurea lappa) and Palashabeeja (seed of Butea monosperma). ${ }^{20}$

\section{DISCUSSION}

Gruhadhuma is chimney soot that has a role in the management of various poisons in Ayurveda. It is used in combination with other herbs. Formulations having it are used through various modes of administration. They are used internally, as nasya, anjana, lepa, etc. As it is a carbon compound it may probably bind with the poison and act as an antidote. The processing of it with other herbal and mineral drugs using different media increase its antipoisonous effect and thus used in different formulations. These yogas are not just used in the treatment of poisons but also in complications of poison and also other diseases conditions like kushta, etc.

\section{CONCLUSION}

An insight through the agada yogas mentioned for the treatment of various animate poisons reveal the use of gruhadhuma in various forms; as pana (internal use), anjana (collyrium), lepa (anointment), etc. Thus gruhadhuma probably acts as an antidote in various poisons. Not just in the management of poisons but also in the complications of poisons also it is said to be administered. It is used not as a single drug but as a combination with other herbal drugs. In the management of skin diseases also a formulation containing gruhadhuma is said. There is a wide scope of research with these formulations as these are not touched upon.
11. K. R Srikantha Murthy. Ashtanga Sangraha of Vagbhata.Uttarasthana, chapter 42, verse $36.1^{\text {st }}$ edition, Varanasi; Chaukambha Orientalia: 1997:394

12. K. R Srikantha Murthy. Ashtanga Sangraha of Vagbhata.Uttarasthana, chapter 46 , verse $20.1^{\text {stedition, }}$ Varanasi; Chaukhmaba Orientalia: 1997:434

13. K. R Srikantha Murthy. Ashtanga Sangraha of Vagbhata. Uttarasthana, chapter 47, verse28.1 ${ }^{\text {st }}$ edition, Varanasi; Chaukambha Orientalia: 1997:444

14. K. R Srikantha Murthy. Ashtanga Sangraha of Vagbhata.

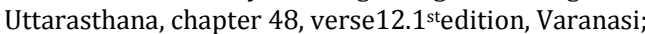
Chaukambha Orientalia: 1997:453

15. K. R Srikantha Murthy. Ashtanga Sangraha of Vagbhata.

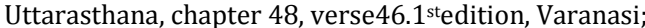
Chaukambha Orientalia: 1997:456

16. K. R Srikantha Murthy. Ashtanga Hrudaya of Vagbhata. Uttarasthana, chapter 36, verse59.1 ${ }^{\text {stedition, Varanasi; }}$ Krishnadas Academy: 1995:352

17. K. R Srikantha Murthy. Ashtanga Hrudaya of Vagbhata. Uttarasthana, chapter 36, verse67.1 ${ }^{\text {st }}$ edition, Varanasi; Krishnadas Academy: 1995:354

18. K. R Srikantha Murthy. Ashtanga Hrudaya of Vagbhata. Uttarasthana, chapter 38, verse18.1 ${ }^{\text {st }}$ edition, Varanasi Krishnadas Academy: 1995:377

19. PV Sharma. Sushrutha Samhita. Kalpasthana, chapter 8 , verse46-7.Reprint edition, Varanasi; Chaukambha Vishwabharati: 2010:86

20. PV Sharma. Sushrutha Samhita. Kalpasthana, chapter 8 verse47.Reprint edition, Varanasi, Chaukambha Vishwabharati: 2010:86 